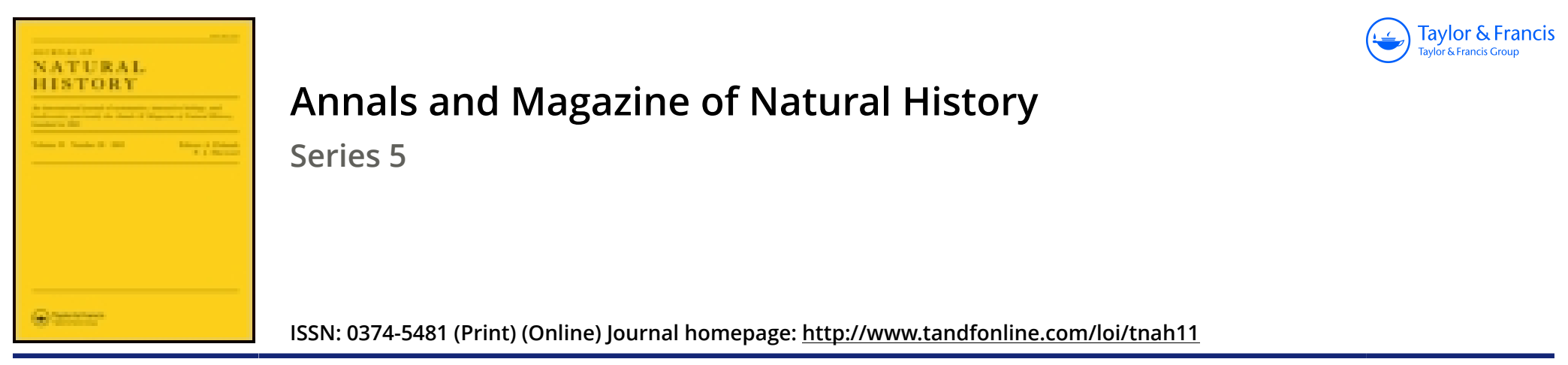

\title{
XV.-Descriptions of new species of Lepidoptera, chiefly from Duke-of-York Island and New Britain
}

\author{
Arthur G. Butler F.L.S. F.Z.S.
}

To cite this article: Arthur G. Butler F.L.S. F.Z.S. (1882) XV.-Descriptions of new species of Lepidoptera, chiefly from Duke-of-York Island and New Britain , Annals and Magazine of Natural History, 10:56, 149-160, DOI: 10.1080/00222938209459684

To link to this article: http://dx.doi.org/10.1080/00222938209459684

\section{Published online: 07 Oct 2009.}

\section{Submit your article to this journal $\square$}

Џ Article views: 2

Q View related articles $\square$

Citing articles: 1 View citing articles $\square$ 
"Our form must be associated with the family Loricata (Palinurides, Scyllarides) because it presents the characters which distinguish this family from the other group of Macrurous Decapod Crustacea, $i$. $e$. the absence of a protective lamella, or scale, to the external antennæ, the monodactyle feet, and the structure of the peduncle of the outer anterna, which is composed of three joints, of which the first two are intimately united with the epistoma, a peculiarity which is met with only in the Loricata. Nevertheless it departs from the Palinurides and the Scyllarides by the non-triangular sternum and by a different habit. It must therefore form a new genus and a new subfamily in the group of the Loricata."

[To be continued.]

XV.-Descriptions of new Species of Lepidoptera, chiefly from Duke-of-York Island and New Britain. By AnTHuR G. Butlen, F.L.S., F.Z.S., \&c.

[Continued from p. 43.]

18. Libythea pulchra, sp. n.

Allied to $L$. Geoffroyi and $L$. antipoda. Wings above bright lilac, the whole disk of the secondaries bright fulvous orange, borders of all the wings narrowly dark brown; veins brown: thorax blue-green, tips of palpi and shoulders brown; abdomen brown, bluish at base, greyish brown spotted with black at the sides. Primaries below ochraceous, apical area brown crossed by a vague band of greyish lilac; borders brown, the costa traversed by darker striations: secondaries rosy lilacine, alternating with four bands of bronze-brown and striated with the same colour: body ashy whitish, the pectus bluish at the sides. Expanse of wings 57 millim.

New Britain.

\section{Curetis solita, sp. $\mathrm{n}$.}

o. Primaries above dark chocolate-brown, with the lower half of the discoidal cell and a large oval patch confluent with it upon the median interspaces, bright orange: secondaries slightly paler than the primaries, with slight purplish and bronze reflections; an elongate subapical orange spot and a few scales of the same colour beyond the cell: body as usual. Under surface snow-white, with slightly sordid margins and brown fringes to the wings; a few scarcely perceptible slender grey dashes across the disk, and a submarginal series of black dots. Expanse of wings 41 millim. 
New Britain.

Allied to C. celebensis.

20. Holochila regina, sp. n.

Near to $H$. intensa: the male of the same brilliant cobaltblue, but with the external black border of primaries of only two thirds the width at apex; the female also very similar to that sex of $H$. intensa, but with the white spot more completely concealed by a bright silvery blue shot, so that in some lights it is quite confluent with the interno-median patch of silvery blue. Expanse of wings, of 30 millim., of 29 millim.

Duke-of-York Island.

We have males of this species from New Guinea.

\section{Miletus scintillans, sp. $\mathbf{n}$.}

б. Allied to $M$. anacletus, but the wings above of a shining greenish cobalt-blue (instead of ultramarine), and with the black apical area of primaries slightly narrower; on the under surface the submarginal metallic spots are slightly pink, like tarnished silver, instead of golden green; all the other metallic markings are more golden than in $M$. anacletus; there is a small pale blue spot at the end of the cell of primaries, and below and beyond it are reddish-orange spots, the oblique subapical band is reddish orange instead of ochreyellow; the red bands of secondaries are darker, the first being preceded by a short orange dash, the second decidedly straighter than in $M$. anacletus, the third entirely different in shape, nearly straight from the second subcostal to the first median branch, where it is interrupted and V-shaped to the abdominal margin; the submarginal band inside the metallic spots orange instead of ochre-yellow; external border buff. Expanse of wings 36 millim.

New Britain.

The blue colouring of this beautiful species is more like that of $M$. epicletus than $M$. anacletus; but the pattern of the under surface more nearly approaches that of the latter species. In both the colouring above and some of the undersurface characters it approaches the Fabrician type of $M$. narcissus, which leads off from it in the direction of $M$. pythias.

\section{Lampides astarte, sp. n.}

․ Above grey. The wings with vivid sky-blue reflections; markings much like those of Lyccenesthes larydlas, Hew. (nec Cramer)*; the primaries with rather a broad ex-

* Cramer's figure is not at all like Hewitson's insect on either surface. I am somewhat doubtful as to whether it is even a Lycanesthes. 
ternal blackish border, upon which a submarginal paler lunated line is dimly visible; the inner edge of this border is bounded by a diffused white line: secondaries with an oblong blackish spot just beyond the cell; a rather broad blackish external border with undulated white inner edge, and enclosing a marginal series of dull black spots with lunate white inner borders; tail short, black, tipped with white: abdomen brownish. Wings below with the basal half pale brownish grey; the secondaries crossed by irregularly placed oblong darker patches edged with blackish and white; the primaries with only one such patch at the end of the cell, external half snow-white, an irregular blackish-bordered grey-brown band crossing the disk immediately beyond the basal area ; a submarginal undulated blackish stripe, followed by a marginal series of blackish spots, the last two on the secondaries intense black sprinkled with metallic blue scales, the last but one being large, the blue scaling confined to its outer margin, and its inner edge bounded by a pale stramineous lunule; $a$ black marginal line; fringes spotted with blackish at the extremities of the veins; tail as above: body below white, the legs greyish. Expanse of wings 29 millim.

New Britain.

\section{Lampides complicata, $\mathrm{sp} . \mathrm{n}$.}

q. Allied to L. argentina. Wings above pale blue-grey; primaries with a broad apical area and external border dark grey-brown; a small black spot at the end of the cell; a slender abbreviated white submarginal line near external angle: secondaries with a marginal series of white-edged conical grey-brown spots, bounded internally by an undulated line of the same colour, the sixth spot blackish and surmounted by a small orange spot. Under surface pale stonebrown, with white-bordered darker brown markings as follows :- two irregular oblong spots closing the discoidal cells and enclosed by two continuous irregular bands connected with the extremities (that is to say, on the costal border of primaries and the abdominal border of secondaries); a continuous undulated (or almost zigzag) submarginal whitebordered brown stripe, limiting the marginal conical spots, which are continued to the apex of primaries, the last two on secondaries being partly black and surmounted by orange; a slender brown marginal line; fringe white; tail blackish, with whiter outer margin and tip. Expanse of wings 24 millim.

"New Britain" (in accompanying list of specimens).

A ticket on the specimen indicates that it is from Duke-ofYork Island. 


\section{Amblypodia minnetta, sp. $\mathrm{n}$.}

8. Nearly allied to $A$. helius, from which it differs in its smaller size and the narrower black external border to its wings above, and below in the considerably smaller size of all the white-edged black-brown spots, none of which consequently are confluent, so that the discal bands consist of chain-like series of white-edged spots. Expanse of wings 41 millim.

Duke-of-York Island.

There is a pair of what appears to be this species in the Hewitson collection, from New Guinea. The specimens are arranged under $A$. helius.

\section{Hypolyccena periphorbas, sp. n.}

․ . Allied to H. phorbas and H.tmolus. Upper surface much like the same sex of the latter species, but the white patch on the primaries smaller, not bluish; the secondaries shorter, not so grey, with four well-defined whitish-edged blackish submarginal spots above the tails. Under surface brassy instead of pure white, excepting a patch on the primaries corresponding with the white patch of the upper surface; the short bars closing the discoidal cells and the discal band ochreous instead of pale stone-colour; the discal band widely interrupted in the centre on the primaries, and much more irregular on the secondaries; the ocelloid marginal band much more defined, the spots enclosed within it distinctly conical on the secondaries. Expanse of wings 36 millim.

New Britain.

\section{Delias Salvini, sp. n.}

đ. Near to $D$. bago ë (=eurygania); but the primaries on both surfaces with a small curved oblique subapical white band in place of the large sulphur-yellow patch of D. bagoë; the secondaries below with the crimson tapering submarginal band much more arched, so that its outer edge is almost parallel to the outer margin. Expanse of wings 65 millim.

New Britain.

\section{Elodina primularis, sp. n.}

Sulphur-yellow; primaries with dark bronze-brown costal and external borders formed as in E. therasia (=bouruensis?), but decidedly wider: secondaries with three squamose brown spots at the extremities of the second subcostal, radial, and third median branches; abdominal border white: body greenish grey. Primaries below sulphur-yellow, very bright 
towards the base; an arched brown band from the costal border beyond the cell to the outer margin near external angle; apical area cream-colour; fringe dark brown: secondaries cream-colour. Expanse of wings 45 millim.

Duke-of-York Island.

\section{Appias delicata, sp. n.}

ð. Allied to A. celestina. Pale chalky blue, with the veins on external area of primaries and a tapering external border black : secondaries with the second subcostal, radial, and third median veins terminating in diffused black spots; abdominal border whitish: body blue-grey. Under surface bluish white; primaries with a blackish squamose streak from the fifth subcostal or upper radial branch to the external angle, uniting upon the veins with a tapering internally sinuated marginal grey band: secondaries with the basal half of costal area bright sulphur-yellow; discoidal cell and disk creamy yellowish, shading off externally into a submarginal diffused greyish band united on the veins to a grey border, so as to leave four or five large spots of the ground-colour; base of abdominal border and pectus pale sulphur-yellow. Expanse of wings 73 millim.

New Britain.

29. Belenois picata, sp. n.

$\delta$. Allied to B. teutonia of Australia, but differing on both surfaces in the much larger submarginal white spots, and on the under surface in the total absence of all the orange patches and spots. Expanse of wings 64 millim.

New Britain.

As Donovan gives perfectly recognizable figures of $B$, teutonia (omitting only the small black discocellular line on the male) it is unnecessary to describe $B$. picata in full.

\section{Zetides seminigra, sp. n.}

Differs from $Z$. agamemnon above in the greater size of the subcostal spots beyond the cell of primaries, in the more emerald-green colour of the spots of the oblique postmedian series, in the continuation of this series to the inner margin by the introduction of two large spots placed transversely instead of the three small obliquely placed spots of $Z$. agamemnon, thus leaving a clear space throughout between the postmedian and submarginal series, in the more uniform size of the spots of the latter series (which terminates in two small unequal spots in place of the large double one of $Z$. agumem- 
non), in the almost total absence of the green and white markings on the secondaries, in the much less prominence of the pink coloration on the under surface and of the green spots on the secondaries, in the paler colour of such spots as remain, in the presence of a red-bordered black spot towards the base of the costal border, immediately above the ordinary lunule of these colours, in the presence of two conspicuous scarlet spots in place of the two other ordinary red-edged black spots, and in the greater size of the black patch beyond the middle of the subcostal area. Expanse of wings 100 millim.

New Britain.

31. Plesioneura insulata, sp. $\mathrm{n}$.

万. Allied to P. alysos of Ceylon. Dark chocolate-brown; primaries with an oblique trifid semihyaline white patch from the subcostal vein near the end of the discoidal cell to the first median branch; a small transverse bilobed spot separate from the above, but of the same colour, across the internomedian area near the external angle. Expanse of wings 43 millim.

New Britain.

\section{Tagiades clericus, sp. n.}

Nearly allied to T. atticus : primaries dark purplish brown, with two conspicuous hyaline white spots near the end of the cell and two placed obliquely near the base of the median interspaces; an oblique and slightly angulated subapical series of four hyaline white points : seeondaries dark brown, with the anal fourth snow-white; the apex, three large marginal spots, and two unequal obliquely placed subapical spots black : body dark brown. Primaries below nearly as above : secondaries snow-white, bluish in the centre, and with the base and costal area broadly purplish brown; a subconfluent marginal series of unequal black spots; three small subapical black spots, the second and third close together, on the radial interspaces : pectus bluish white; venter white. Expanse of wings 52 millim.

Duke-of-York Island.

33. Tagiades presbyter, sp. $\mathrm{n}$.

Allied to T.atticus and T. menaka: primaries above blackbrown; a subcostal dot and two unequal dots near the end of the cell, forming an oblique series beyond the middle; two dots placed obliquely on the median interspaces, the usual five subapical dots, a squamose dash at the end of the cell, and 
another near the external angle hyaline white: secondaries with the basal half and apical area black-brown; remainder of wing, with the exception of a large submarginal black spot and a black border confluent with the apical area, snowwhite : body dark brown. Primaries below with the squamose spots replaced by well-defined snow-white spots, that near the external angle large and bifid; otherwise nearly as above: secondaries snow-white, pale blue towards the base; costal area, a subapical spot near the outer margin, and a narrow external border black: body below white; pectus and legs slightly bluish. Expanse of wings 46 millim.

Duke-of-York Island.

\section{Pamphila repetita, sp. $\mathrm{n}$.}

ð. Extremely like $P$. ancillaris of the Amazons. Dark bronze-brown: primaries with a chocolate-coloured patch below the cell, bounded externally by a slender oblique hyaline white line from first median branch to submedian vein; two hyaline white dots placed obliquely in the median interspaces. Under surface paler, with golden reflections : primaries with hyaline markings as above. Expanse of wings 31 millim.

Duke-of-York Island.

\section{Pamphila albiclavata, sp. $\mathbf{n}$.}

万. Chocolate-brown; basal half of wings above clothed with ochraceous scales: primaries with three or four bright ochreous spots in an oblique series from the third median branch to the submedian vein: secondaries with two or three ill-defined ochreous spots on the median and radial interspaces, thus extending the ochraceous-tinted area of the wings: head flecked with ochreous; front of thorax greenish. Wings below chocolate-brown, irrorated with ochreous: primaries with three increasing ochreous spots from third median branch to submedian vein: pectus ochraceous; venter brown, barred with crean-colour; club of antennæ broadly banded with cream-colour. Expanse of wings 35 millim.

Duke-of-York Island.

$P$. albiclavata much resembles the female of the American P. Wingina.

\section{Heterocera.}

36. Macroglossa fulvicaudata, sp. $\mathrm{n}$.

Allied to $M$. alcedo. Primaries above dark pitchy brown, crossed by two inconspicuous sericeous greyish bands, the 
first just before the middle, transverse, slightly wider in front than behind; the second discal, its inner edge extending from the inner margin close to external angle to the apical third of costa; these bands are limited internally by nearly straight blackish lines; the first is also bounded externally by an irregularly-undulated line, but the second band has a diffused outer margin *: secondaries with the submedian vein, the median vein with its branches, and a very broad external border occupying half the wing black; the rest of the wing bright orange-ochreous, paler upon the costal border: head and thorax greyish olivaceous, with chocolate-brown patches on each side behind; abdomen dark purplish brown, with the three basal segments orange at the sides, and the remaining segments with orange lateral tufts; anal tuft deep orange. Wings below chocolate-brown : primaries with a small basal ochreous patch: secondaries with the basiabdominal third bright ochreous, but with brown anal margin; three parallel dark-brown lines from costa to submedian vein, across the centre of the wing: palpi and front of pectus white, remaindex of pectus pale ochreous; venter ochreous, with triangular ferruginous patches on each side; anal tuft bright ochreous. Expanse of wings 56 millim.

New Britain.

The example in our collection from New Ireland is larger, measuring 64 millim. in expanse.

\section{Macroglossa calescens, sp. $\mathrm{n}$.}

Primaries above dark purplish brown, mottled with sericeous grey; a rather ill-defined black band forking above the median vein before the middle, and two parallel trisinuate dark-brown lines across the disk : secondaries bright saffronyellow, with two basal patches below the median vein, and a very broad external border, abruptly tapering at anal angle, but occupying about half the wing, dark purplish brown: head and thorax greyish olivaceous, with a sprinkling of ash-grey scales, dark reddish brown behind; abdomen dark laky brown, with metallic-green scales along the posterior margins of the segments, the three basal segments with deeporange lateral patches; lateral margins of segments blood-red. Primaries below dark purplish brown, gradually shading into blood-red towards the external border, which is irregularly black-brown; extreme base ochreous: secondaries deep

* A specimen in the collection from New Ireland, presented by Messrs. Salvin and Godman, shows no trace of the blackish lines; but it is somewhat worn, and may have lost them. 
sienna-red, shading into blood-red towards the external border, which is black-brown; abdominal area blight ochreous; three dark-brown stripes a little wider apart than in the preceding species: palpi and pectus ashy white; legs greybrown; venter blood-red, irrorated with orange, with steelblue scales along the posterior margins of the scales; anus brown. Expanse of wings 53 millim.

New Britain.

Although a broader-winged insect, the style of coloration in this species on both surfaces is very like that of $M$. catapyrrha.

\section{Rhamphoschisma Godeffroyi, sp. n.}

Primaries above pale silvery brown, slightly clouded with olivaceous, crossed in the middle by a broad $\mathbf{X}$-shaped dark olivaceous double belt, beyond which the disk, with the exception of the apical area and a small patch at external angle, is of a still darker olivaceous colour ; an apical costal patch reddish olivaceous, only separated by a zigzag silvery line from a large irregular black-brown patch on the external border: secondaries dark purplish brown, paler at base, crossed in the middle by a rather narrow bright ochreous band, its outer edge deeply incised below the first median branch; costal border greyish brown: body greyish brown; tegulæ reddish brown, with black margins and whitish fringe: abdomen black at the sides, the three basal segments with ochreous spots, increasing in size and intensity from the base backwards; posterior segments with reddish-orange lateral tufts; terminal segment with a white spot on each side along its anterior margin. Wings below brownish grey, the primaries shading into deep brick-red towards apex and upon the disk; a nearly straight central red-brown stripe and two parallel arched discal stripes of the same colour; external border olivaceous, the inner edge of it sprinkled with pale scales; extreme base cream-coloured: secondaries with a black spot before the middle of costa, from which runs the first of three equidistant dark-brown lines extending from the costal margin to the submedian vein; a fourth irregular submarginal line, terminating in a blackish anal border; a broad ochreous patch on the abdominal area : body below deep flesh-coloured; palpi dull white; inner surface of legs very broadly fringed with long straw-coloured hairs ; centre of venter greyish. Expanse of wings 60 millim.

Duke-of-York Island.

In my 'Revision of the Sphingidæ' I regarded Rhamphoschisma as congeneric with Macroglossa; and if $M$. trochilus 
be accepted as type I must still hold the same opinion. This species, however, will have to stand as type of Psithyros, Hübn.; and therefore in any case Wallengren's genus falls; but if we accept Felder's extension of the genus, it may stand for all such species as have broadly-fringed and pilose legs, and (so far as I can judge from figures alone) would contain $M$. Mitchelii, $M$. imperator, $R$. rectifascia, $R$. scottiarum, and possibly M. tinnunculus. At any rate the hairy-legged species will have to be separated generically from Macroglossa.

\section{Protoparce Schmeltzii, sp. n.}

8. Primaries above much like those of $P$. cingulata, excepting that the black markings are all replaced by dark velvety grey-brown, the two elongated median stripes being only partly visible in certain lights; discocellular spot white: secondaries ash-grey, crossed at basal fourth by a very oblique brown band, in the centre by two brown stripes, which unite and are continued as a single line from below the first median branch; external border broadly brown, especially at apex; all these brown bands, as well as the costal border, which is whitish, are slightly shot with gold; fringe white, broadly spotted with brown: thorax grey, with several longitudinal black lines; an arched line at the back of the collar on each side: abdomen dark grey in the dorsal region, but with the sides alternately banded with black and white; a bright ochreous spot on each side at the base. Wings below sericeous brownish grey, with feebly indicated darker stripes somewhat as above: body below greyish white; venter with snow-white posterior borders to the segments. Expanse of wings 108 millim.

Australian region.

No reference is given to this species in the list received with the collection; and therefore I am unable to record the exact locality. It is an exceedingly distinet species, intermediate between the $P$. carolina and $P$. cingulata groups.

\section{Spilarctia turbida, sp. n.}

\%. Allied to S. rosacea and S. basilimbata of Japan. Primaries cream-coloured, clouded all over the central area with brown, upon which the veins and a spot at the inferior angle of the cell show creamy white; two large black spots crossed by the median vein, the first near the base and the second at origin of first median branch; two abbreviated oblique black bands divided by the nervures, the first from apex to third median branch, the second from the lower radial at the end of 
the cell to the first median branch; several small black spots and dots are also scattered over the surface near to the costal, external, and internal borders: secondaries rose-pink, creamcoloured at external border; a large black spot at the end of the cell, a smaller oval submarginal spot on the radial interspace, and two unequal spots placed obliquely near the anal angle: thorax sordid cream-colour; margins of collar slightly rosy; two black spots on the collar, a black dash on the tegulæ, and a longitudinal black central stripe on the thorax: abdomen bright rose-pink, with dorsal and lateral series of black spots. Wings below pinky white, the primaries with the basal two thirds washed with vermilion; the black markings nearly as above : secondaries with the discocellular black spot extended as an oblique streak to costa; pectus smokybrown, sparsely clothed with bright rose-red hairs; venter cream-coloured. Expanse of wings 45 millim.

Duke-of-York Island.

The Chelonia costata of Boisduval, both sexes of which are in the collection from Duke-of-York Island, is apparently a species of Phissama. M. Boisduval says, "L'abdomen avec trois rangées de points noirs en dessus et deux en dessous, ce qui la distingue de Fulvia, laquelle Donovan a représentée avec l'abdomen entièrement jaune." But the Museum copy of Donovan shows three dorsal spots on the abdomen, and were they entirely omitted it would probably only be due to the rubbed condition of Donovan's type. I fear therefore that we shall have to adopt the name of Phissama fulvia for this species.

On the same plate with the latter, Donovan gives a poor figure of the Hypsa eusemioides of Felder as "Noctua versicolor" of Fabricius, whereas the latter is evidently a species with a white costal * stripe, and said to have come from the West Indies, or, as Fabricius says, the islands of America.

\section{Areas hyporhoda, sp. n.}

o. Primaries above ochreous, with a black spot at the end of the cell, and two on the basal half of the internal border: secondaries rose-colour, with a black spot at the end of the cell : thorax ochreous; abdomen rose-red, with dorsal and lateral series of small black spots. Wings below rose-coloured towards the base, ochreous towards the external borders; a black spot at the end of each discoidal cell: body below rose-red, the centre of the venter ochraceous. Expanse of wings 44 millim.

* "Fascia abbreviata alba ad marginem crassiorem." 
q. Much larger and broader than the male, the primaries above without any black spots, and all the wings below of a deeper rose-colour almost to the borders. Expanse of wings 53 millim.

New Britain and Duke-of-York Island.

We have a still larger female (58 millim. in expanse) in the Museum collection, presented by Messrs. Salvin and Godman : it was received from New Ireland; and hitherto I have regarded it as probably the female of the more narrow-winged, paler, and somewhat differently spotted Aloa bifrons of Walker. The receipt of the true male, however, puts this quite out of the question; indeed I am of opinion that $A$. bifrons, with its elongated narrow wings, is congeneric with Cramer's Phaloena amasis, and I would suggest its being placed with it under Hübner's generic name Rhodogastria; the first two species placed under the latter group by Hübner fall into other genera.

\section{Damalis tigrina, sp. n.}

o. Bright ochreous; primaries deeper-coloured at the base; with the exception of a large patch at the end of the cell, the apical half of the costal border, and the base, all the interspaces enclose longitudinal broad blackish stripes : abdomen with dorsal and lateral series of black spots. Under surface ochreous, the wings with a decreasing border of internervular black stripes; primaries with black costal margin; collar, prothorax, and front of pectus orange-ochreous. Expanse of wings 56 millim.

New Britain.

Nearest to $D$. nebulosa from Borneo, Malacca, and the Andaman Islands.

[To be continued.]

XVI.-Contributions towards a General History of the Marine Pulyzoa. By the Rev. Thomas Hincks, B.A., F.R.S.

[Continued from vol. ix. p. 127.]

[Plates VII. \& VIII.]

X. FOREIGN CHEILOSTOMATA (Miscellaneous).

Family Eucratiidæ.

Rhabdozoum, nov. gen.

Der. $\boldsymbol{\alpha} \alpha \dot{\beta} \delta o s$, a rod, and $\zeta \hat{\omega} o \nu$, an animal.

Gen. char.-Zoarium erect, phytoid, composed of numerous 